\title{
Resiliency as a predictor of flexibility in coping with stress of cardiac patients
}

\section{BACKGROUND}

Since cardiovascular diseases remain the main cause of premature mortality in men and women in Poland, it is reasonable to look for factors that protect against these conditions. Psychological resiliency is one of such properties that support adaptation in difficult situations and conducive to adaptation to the disease. The aim of the present study was to analyze the relationship between resiliency and flexibility in coping of cardiac patients and to determine whether resiliency is a predictor of flexibility in coping with stress in this group.

\section{PARTICIPANTS AND PROCEDURE}

In the study the Assessment of Resiliency Scale (SPP-25) and the scale of Flexibility in Coping with Stress (KERS-14) were used. The participants of the study were 120 cardiac patients (72 men and 48 women) at the age 29-75.

\section{RESULTS}

The results show that there is a statistically significant relationship between resiliency and flexibility in coping.
Each of the resiliency dimensions, as well as the result of the overall resiliency, correlates positively with each of the dimensions of flexibility in coping. The analysis showed that resiliency is an important predictor of a dependent variable - flexible in coping.

\section{CONCLUSIONS}

There is a positive relationship between resiliency and flexibility in coping with stress in cardiac patients. People with a higher intensity of resiliency in comparison to people with lower intensity of resiliency are characterized by greater flexibility in coping with stress. The dimensions of resiliency, in particular 'Persistence and determination in action' and 'Openness to new experiences and sense of humor', together with the duration of the disease, play a predictive role for flexibility in coping with stress.

\section{KEY WORDS}

resiliency; flexibility in coping; cardiac patients; stress

organization - Casimir the Great University, Bydgoszcz, Poland

AUthors' CONTRibutions - A: Study design - B: Data collection - C: Statistical analysis - D: Data interpretation .

E: Manuscript preparation · F: Literature search · G: Funds collection

CORRESPONDIng AUthor - Katarzyna Góralska, Casimir the Great University in Bydgoszcz, 30 Chodkiewicza Str., 85-064 Bydgoszcz, Poland, e-mail: katarzynagoralskaa@gmail.com

TO CITE THIS ARTICLE - Góralska, K., \& Basińska, M. A. (2019). Resiliency as a predictor of flexibility in coping with stress

of cardiac patients. Health Psychology Report, 7(3), 191-199. doi: https://doi.org/10.5114/hpr.2019.85952

RECEIVED 18.10.2018 · REVIEWED 15.04.2019 • ACCEPTED 17.04.2019 • PUBLISHED 12.06.2019 


\section{BACKGROUND}

Cardiovascular diseases (CD) are by far the largest threat to the lives of Poles, representing the most common cause of mortality - almost half of all deaths in our country are caused by CD. Although a decline in the frequency of deaths for this reason has been observed for several years, $C D$ remains the main cause of mortality, significantly exceeding the death rate due to cancer (Cierniak-Piotrowska, Marciniak, \& Stańczak, 2015).

Katarzyna Góralska, Małgorzata A. Basińska

Currently, the etiopathogenesis of cardiovascular disease is attributed to significant psychosocial factors, among which chronic stress, low level of social support, specific personality traits (personality type A, personality type $\mathrm{D}$ ) and depression are most often distinguished (Gil et al., 2006; Shen, Myers, \& McCreary, 2006; Strike \& Steptoe, 2004). The specific characteristics of an individual may not only play the role of risk factors, but may also have a protective function, and despite numerous loads and accumulating stressors they may facilitate coping with them (Szwajca, 2014a). Psychological resiliency is one of such properties that support adaptation in difficult situations (Szwajca, 2014b).

\section{PSYCHOLOGICAL RESILIENCY}

The construct of resiliency has aroused more and more interest of researchers recently. There are two terms in the literature: resilience and resiliency. The first term is identified with the process of successfully overcoming negative life events and is often referred to as resistance (resilience). On the other hand, the second term, resiliency, means the personality property or relatively permanent resource of an individual. This approach to is related to the Blockego-resiliency theory (Block \& Block, 1980; Block \& Kremen, 1996), which describes it as a relatively permanent disposition, determining the process of flexible adaptation to the ever-changing life requirements. Block treats resiliency as a personality trait that is important in the process of dealing with traumatic situations and events occurring in everyday life. Resiliency is the opposite of a lack of control (impulsiveness) as well as its excess (stiffness), because it is related to the individual's ability to adjust the level of control to their own abilities and characteristics of the situation experienced. Fredrickson (2001) also presents resiliency as the subjective property of an individual, describing it as a permanent resource of an individual, usually arising as a result of a person encountering serious difficulties or threats. In Poland, this understanding is shared by Uchnast (1997) and Oleś (2000), using the term "resiliency-ego". According to Ogińska-Bulik and Juczyński (2008a) resiliency is a self-regulating mechanism that includes cognitive, emotional and behavioral elements. The cognitive elements of resiliency are characteristic for beliefs and expectations and concern, among other things, perceiving reality in terms of challenge, as well as own competences. Emotional components of resiliency are associated with positive affect and emotional stability. The behavioral components of resiliency manifest themselves in the search for new experiences and the use of multiple and effective strategies to deal with problems.

Psychological resiliency supports perseverance and flexible adaptation to life's demands, improves mobilization to take remedial actions in difficult situations, and increases the tolerance of negative emotions and failures. A person characterized by a high degree of resiliency has a more positive approach to life, is emotionally stable, perceives difficulties more often as an opportunity to gain new experiences, and considers itself as an entity that influences decision-making (Shen et al., 2006; Ogińska-Bulik \& Juczyński, 2011; Semmer, 2006). Previous studies have shown the importance of psychological resiliency for the functioning of people in different situations, especially those experiencing negative life events (Felcyn-Koczewska \& Ogińska-Bulik, 2011; Ogińska-Bulik, 2010, 2012, 2013, 2015; Ogińska-Bulik \& Juczyński, 2012). It was also shown that resiliency plays the role of a protective factor against the negative effects of experienced occupational stress (Ogińska-Bulik, 2011a), conducive to adaptation to the disease (Ogińska-Bulik \& Juczyński, 2012; Kasprzak, Basińska, \& Lewandowska, 2013; OgińskaBulik, 2011b; Sęk, Kaczmarek, Ziarko, Pietrzykowska, \& Lewicka, 2012; White, Driver, \& Warren, 2010) and supporting adaptive functioning in difficult life situations (Grzankowska, Napora, \& Basińska, in print). The dynamism can be developed and shaped by strong motivation and willingness to learn and a flexible approach to life experiences.

\section{FLEXIBILITY IN COPING}

The concept of flexibility in coping with stress introduces changes to the understanding of coping. The change of perspective consists in moving away from analyzing coping from the point of view of styles and strategies, accentuating its course and effectiveness. Flexibility in coping puts more emphasis on the way the strategy is applied than on its type and emphasizes the individual's ability to effectively change the coping strategies used depending on the requirements related to the stressful situation. Flexibility in this sense appears to be a property, a characteristic of how an individual deals with difficult situations. The more flexible a person is in coping with stress, the more effective is their adaptation to it (considered from different perspectives: ethics, somatic health, 
social functioning and the ability to preserve remedial resources) (Kato, 2012; Basińska, 2015).

Reports of flexible coping have been occurring for years. Cheng in her research showed that flexible coping is a combination of three processes: 1) changeability of cognitive assessment and coping patterns depending on the situation, 2) matching coping strategies to the situation, and 3) assessing the effectiveness of coping with stress (Cheng, 2001). The theory of flexible coping which is the basis of the present research is based on these three processes and refers to the cognitive-transactional concept of stress of Lazarus and Folkman (1984). Kato (2012), the author of one of the constructs of flexible coping, also refers to the transactional theory of stress, accentuating its processual nature and actions aimed at achieving positive results taken. Flexible coping is defined as "an individual's ability to stop using ineffective coping strategies and to create and implement alternative coping strategies" (Kato, 2012, p. 263). Flexible coping, according to Kato, includes two processes: evaluation coping, i.e. the ability to evaluate the effectiveness of the applied strategy and discontinue its use, when this assessment proves to be negative, and adaptive coping, i.e. the ability to generate a new remedy and apply it in place of the ineffective one (Kato, 2012).

Studies carried out in Poland, using the Kato questionnaire for flexible coping, did not give satisfactory results, which may be due to intercultural differences, hence the attempt to introduce a new understanding of flexibility in coping with stress (Basińska et al., in print). The theoretical basis of flexibility in coping with stress in Polish studies was based mainly on the transactional theory of stress of Lazarus and Folkman (1984), in which the understanding of coping is included in the category of the process, which aims to effectively cope with the existing loads. Lazarus and Folkman (1984) distinguished three types of assessments, occurring subsequently and corresponding to the dynamics of the stress transaction. In an aggravating situation, the first one, considered as primary appraisal, assesses the situation as being stressful or not. The next step is the assessment of one's own remedial resources (secondary appraisal). After their application, the entity evaluates the effectiveness of the applied strategy (reappraisal) and determines whether the stressful situation has been successfully solved or is still being dealt with. Flexibility in coping is characterized by changeability referred to by Lazarus and Folkman (1984) as interinterventional changeability, i.e. the use of different coping strategies according to changing situational conditions and in-situ changeability, emphasized by Kato (2012), related to the selection of strategies for coping with stress in response to a change in the assessment of a stressful situation, i.e. also when objective circumstances have not changed.
The flexibility in coping with stress is based on a rich and diverse resource of remedial (cognitive and behavioral) strategies that the individual skillfully adapts to the changing conditions of stressful transactions or appropriately to the assessment of the effectiveness of the techniques used. Another manifestation of flexibility in coping includes the individual's ability to critically analyze the applied strategies and to reflect their effectiveness, also in the context of future behavior (Basińska et al., in print).

\section{OBJECTIVE OF RESEARCH AND HYPOTHESES}

Resiliency predictor of flexibility in coping

In the context of the above considerations, it was assumed that patients suffering from cardiovascular diseases characterized by a higher resiliency will be more flexible in coping, which is particularly important due to the dynamics of disease changes and their quality of life. Due to the fact that these are chronic diseases, it was decided to evaluate the significance of the duration of the disease for the relationship between the analyzed variables. The aim of this study was to analyze the relationship between resiliency and its dimensions and flexibility in coping of cardiac patients and to assess whether the dimensions of resiliency with the duration of the disease are predictors of flexibility in coping in this group. Based on theoretical data, the following hypotheses were formulated:

$\mathrm{H}$ 1. There is a positive relationship between resiliency and its dimensions and flexibility in coping with stress in the examined group of cardiac patients.

$\mathrm{H} 2$. The resiliency dimensions along with the duration of the disease play a predictive role for flexibility in coping with stress.

\section{METHODS}

In order to verify the research hypotheses, the Scale of Resiliency Measurement (SPP-25) by OgińskaBulik and Juczyński (2008a) was used, allowing the measurement of the overall resiliency level. Resiliency is treated as a property of personality, and it includes five factors: 1) perseverance and determination in action, 2) openness to new experiences and sense of humor, 3) personal competences to cope and tolerance of negative emotions, 4) tolerating failures and treatment of life as a challenge; and 5) an optimistic attitude to life and the ability to mobilize in difficult situations. These properties are evaluated on a 5-point Likert scale from 0 (definitely not) up to 4 (definitely yes). The overall result of SPP-25 is the sum of the five listed factors, which include 5 items. The higher the intensity of resiliency, the higher the overall score, which can also be expressed on the sten 
Katarzyna Góralska, Małgorzata A. Basińska scale. The scale has obtained satisfactory psychometric properties. The reliability of the scale was determined on the basis of Cronbach's $\alpha$ coefficient, which was .89 for the entire scale and $.67-.75$ for the five subscales (Ogińska-Bulik \& Juczyński, 2008a). Reliability in the studied group is: for the whole scale .93 and from .62 to .81 for subscales.

Flexibility in coping was measured by the Flexibility in Coping Questionnaire (KERS-14) by Basińska et al. (in print). In the adult version, three subscales were distinguished - 1) Repertoire, 2) Changeability and 3) Reflexivity. A subject who scores high on the Repertoire scale is aware of having a wide range of coping strategies. The person is considered competent, able to find new, adequate ways to deal with difficult situations. A high score in Changeability means that the respondent chooses ways of dealing with difficulties that are most appropriate and effective in a given situation. A negative assessment of the effectiveness of the strategy applied changes the way of coping. A high score on the Reflexivity scale means that the individual is able to reflect on the coping strategies applied, to reflect on the values used, and to accept the difficult situation in which one finds oneself. The questionnaire consists of 14 statements to which the subject responds by selecting one of four responses from 0 (never applies) to 3 (always applies). The higher the score the respondent gets, the more flexible they are in coping with stress. The scale has obtained satisfactory psychometric properties. Cronbach's $\alpha$ coefficient of reliability for subscales Repertoire, Changeability, Reflexivity and the overall result were: .96, .97, .73, .98 (Basińska et al., in print). Reliability in the studied group is: for the whole scale .98 and for subscales from .73 to .98 .

\section{PARTICIPANTS AND PROCEDURE}

The study included 120 people with cardiac disease. The study was voluntary and anonymous. The patients were informed about the purpose of the research and about the possibility of refusing to participate at any stage. The study was conducted at the 10th Military Clinical Hospital with the Polyclinic SP ZOZ in Bydgoszcz and at the Hospital in Nowe Miasto Lubawskie from April to September 2017. Participants of the study were patients at the Cardiology and Cardiac Surgery Clinic and on the cardiac ward with a diagnosis of cardiovascular disease. Information on the diagnosis of the disease was obtained from patients and hospital staff - including the branch nurse ${ }^{1}$. Among the study participants were people diagnosed with more than one cardiovascular disease, as well as people burdened with other diseases, but due to their diversity and large numbers groups of patients were not specified. 72 men (60\%) and 48 women (40\%) were subjected to the study. The subjects were between 29 and 75 years old. The average age of men was 56.11 years $(S D=9.24)$. The average age of women was $58.02(S D=8.84)$.

Among the respondents, the largest group included people with secondary education $(n=49$, $41 \%)$ and primary education $(n=32,27 \%), 30$ people $(25 \%)$ declared vocational education, and $9(8 \%)$ higher. Most of the respondents were in marital relationships $(n=73,61 \%) ; 16$ people $(13 \%)$ declared widowhood, 14 people (12\%) an informal relationship, 9 people $(8 \%)$ were separated or divorced, while $8(7 \%)$ remained unmarried. The place of residence of the respondents was varied. The largest number of respondents lived in rural areas $(n=48,40 \%)$ and cities with up to 400,000 residents $(n=29,24 \%)$. Almost half of the respondents were professionally active $(n=54,45 \%)$. Most of the respondents $(n=93$, $78 \%$ ) lived with their family. The subjects were characterized by large variations in the type of chronic disease. The largest number of patients suffered from hypertension ( $n=36,30 \%)$, coronary heart disease $(n=19,16 \%)$ and had a myocardial infarction $(n=10$, $8 \%)$. The respondents also suffered from heart failure $(n=8,7 \%)$, had heart defects $(n=4,3 \%)$, arrhythmia $(n=7,6 \%)$ and heart rate impairment $(n=6,5 \%)$ and other cardiovascular diseases $(n=30,25 \%)$. Duration of the disease, indicated by the respondents, was also characterized by high diversity, as it varied between 1 month and 30 years. The average duration of the disease was 6 years $(S D=5.11)$.

\section{RESULTS}

The results were presented on the basis of descriptive statistics. The results show a wide variety. The average intensity of flexibility in coping with stress in the group of respondents was 20.65, which corresponds to the fifth sten (this is the average level). For Repertoire, Changeability and Reflexivity subscales the average values were $7.36,8.64$ and 4.65 points respectively, which correspond to the fifth, fourth and fourth sten respectively. The intensity of the pressure was on average 68.58 points, which also indicates the 5 th sten.

\section{THE RELATIONSHIP BETWEEN RESILIENCY AND FLEXIBILITY IN COPING WITH STRESS}

In hypothesis 1 , it was assumed that there is a statistically significant positive relationship between resiliency and its dimensions, and flexibility in coping of cardiac patients.

As a result of the conducted analyses, it was found that there is a statistically significant relationship between resiliency and its dimensions and flexibility in 
Table 1

Descriptive statistics for measured variables in the group of cardiac patients $(N=120)$

\begin{tabular}{lrrrr}
\hline Variable & $M$ & $S D$ & $\min$ & $\max$ \\
\hline Flexibility in coping & 20.65 & 10.72 & 0 & 42 \\
Repertoire & 7.36 & 4.08 & 0 & 15 \\
Changeability & 8.64 & 4.94 & 0 & 18 \\
Reflexivity & 4.65 & 2.07 & 0 & 9 \\
Resiliency & 68.58 & 12.37 & 35 & 99 \\
Persistence and determination in action & 13.33 & 3.44 & 5 & 20 \\
Openness to new experiences and sense of humor & 15.23 & 2.20 & 7 & 20 \\
$\begin{array}{l}\text { Personal competences to cope and tolerance of negative } \\
\text { emotions }\end{array}$ & 12.96 & 3.28 & 6 & 20 \\
Tolerance for failure and treating life as a challenge & 14.14 & 2.17 & 8 & 20 \\
$\begin{array}{l}\text { Optimistic attitude to life and the ability to mobilize } \\
\text { in difficult situations }\end{array}$ & 12.92 & 2.95 & 6 & 20 \\
\hline
\end{tabular}

Table 2

Resiliency and flexibility in coping with stress - Pearson r correlation rates

\begin{tabular}{|c|c|c|c|c|}
\hline \multirow[t]{2}{*}{ Variable } & $\begin{array}{l}\text { Flexibility } \\
\text { in coping }\end{array}$ & Repertoire & Changeability & Reflexivity \\
\hline & \multicolumn{4}{|c|}{$r$} \\
\hline Resiliency & $.72^{*}$ & $.73^{*}$ & $.71^{*}$ & $.58^{*}$ \\
\hline $\begin{array}{l}\text { Persistence and determination } \\
\text { in action }\end{array}$ & $.65^{*}$ & $.68^{*}$ & $.64^{*}$ & $.51^{*}$ \\
\hline $\begin{array}{l}\text { Openness to new experiences } \\
\text { and sense of humor }\end{array}$ & $.59^{*}$ & $.57^{*}$ & $.59^{*}$ & $.53^{*}$ \\
\hline $\begin{array}{l}\text { Personal competences to cope } \\
\text { and tolerance of negative emotions }\end{array}$ & $.65^{*}$ & $.66^{*}$ & $.65^{*}$ & $.51^{*}$ \\
\hline $\begin{array}{l}\text { Tolerance for failure and treating life } \\
\text { as a challenge }\end{array}$ & $.58^{*}$ & $.60^{*}$ & $.55^{*}$ & $.49^{*}$ \\
\hline $\begin{array}{l}\text { Optimistic attitude to life and the ability } \\
\text { to mobilize in difficult situations }\end{array}$ & $.66^{*}$ & $.67^{*}$ & $.67^{*}$ & $.49^{*}$ \\
\hline
\end{tabular}

Note. ${ }^{*} p<.001$

coping. Each of the resiliency dimensions, as well as the overall result of resiliency, correlates positively with each of the dimensions of flexibility in coping. Cardiac patients with a greater intensity of resiliency show greater flexibility in coping with stress.

\section{DIMENSIONS OF RESILIENCY AND DURATION OF THE DISEASE AS PREDICTORS OF FLEXIBILITY IN COPING}

To determine whether the dimensions of resiliency and duration of the disease play a predictive role for the flexibility in coping in cardiac patients, regression analysis in the dorsal version was applied.

The analysis showed that the proposed model is statistically significant $(F(6,93)=14.49, p<.001)$ and explains $45 \%$ of the variance. The dimensions of resiliency 'Persistence and determination in action' and 'Openness to new experiences and sense of humor', allowing one to predict the greatest flexibility in coping with stress in cardiac patients, are important predictors of a dependent variable - flexibility in coping. Based on the higher level of resiliency and shorter duration of the disease, it can be predicted that the patients will be more flexible in coping with stress.
Resiliency predictor of flexibility in coping 
Table 3

Dimensions of resiliency and duration of the disease as predictors of flexibility in coping

\begin{tabular}{|c|c|c|c|c|c|c|c|}
\hline Predictor & $b^{*}$ & $\begin{array}{c}S D \\
\text { from } b^{*}\end{array}$ & $b$ & $\begin{array}{c}S D \\
\text { from b }\end{array}$ & $t$ & $p$ & $\begin{array}{c}R^{2} \\
\text { corrected }\end{array}$ \\
\hline $\begin{array}{l}\text { Persistence and determination } \\
\text { in action }\end{array}$ & 0.23 & 0.11 & 0.70 & 0.32 & 2.15 & .034 & \multirow{6}{*}{0.45} \\
\hline $\begin{array}{l}\text { Openness to new experiences and } \\
\text { sense of humor }\end{array}$ & 0.28 & 0.10 & 1.32 & 0.47 & 2.83 & .006 & \\
\hline $\begin{array}{l}\text { Personal competences to cope } \\
\text { and tolerance of negative emotions }\end{array}$ & 0.18 & 0.12 & 0.57 & 0.40 & 1.45 & .150 & \\
\hline $\begin{array}{l}\text { Tolerance for failure and treating } \\
\text { life as a challenge }\end{array}$ & -0.07 & 0.12 & -0.36 & 0.62 & -0.58 & .563 & \\
\hline $\begin{array}{l}\text { Optimistic attitude to life and } \\
\text { the ability to mobilize in difficult } \\
\text { situations }\end{array}$ & 0.16 & 0.13 & 0.59 & 0.48 & 1.24 & .220 & \\
\hline Disease duration & -0.05 & 0.08 & -0.10 & 0.16 & -0.62 & .537 & \\
\hline
\end{tabular}

\section{DISCUSSION}

Since cardiovascular diseases are the main cause of premature mortality in men and women in Poland, it is reasonable to look for factors that protect against these conditions. Currently, the etiopathogenesis of heart and vascular disease is attributed to increasingly important psychosocial factors (Opuchlik, Wrzesińska, \& Kocur, 2009). The specific human properties have protective functions and despite numerous loads and cumulative stressors they help in constructive coping with life difficulties (Szwajca, 2014a). Psychological resiliency is one of the constructs used to describe a process that reflects a relatively good adaptation (Henderson, 1996). Its essence lies in the ability to adapt to living conditions despite their traumatic character. Flexibility in coping is the ability that consists of: the belief in having sufficient competence to deal with difficulties, the ability to apply strategies appropriate to the situation, and the individual's readiness to think about coping strategies.

As a result of the conducted analyses, it was found that there is a statistically significant relationship between resiliency and flexibility in coping. Each of the resiliency dimensions, as well as the overall result, correlates positively with each of the dimensions of flexibility in coping. The relationship of these variables is confirmed by the theoretical background of the constructs under consideration, as well as by previous studies. Resiliency plays a significant role in coping with life stress (Nadolska \& Sęk, 2007). It can be considered a resource, and defined as a set of skills that lead to effective coping in traumatic situations and everyday difficulties, mainly due to the ability to flexibly and creatively use personal resources and the ability to break away from experiencing negative emotional states (Sęk, 2008). The resiliency is also characterized by flexibility in behavior, in which it is similar to flexibility in coping. The authors Block and Kremen (1996) believe that resiliency, together with related self-control, are the basic personality traits that help explain the functioning of well-performing people. In addition, resiliency is considered a superior resource in coping with stress (Turkiewicz-Maligranda, 2014). It is a construct that has a superior role in relation to other resources, because it includes cognitive elements (e.g. perception of events in terms of a challenge), emotional elements (evoking positive emotions or emotional balance) and behavioral elements (initiating actions in new situations) (Ogińska-Bulik \& Juczyński, 2008b). Therefore, it can be assumed that it has a similar role in relation to flexibility, which is a property of the remediation process and describes the method of applying remedial strategies. Resiliency, as a personality disposition with temperament (Basińska \& Rusek, 2015) will be the basis for flexibility or its lack in the process of coping with stress. The results showing the relationship between resiliency and flexibility in coping are also confirmed in relation to the theory of conservation of resources, formulated by Hobfoll (1989), which was created as a proposition to explain the behavior of a person in a stressful situation. Individuals with diverse and rich personal resources can cope better with current challenges, stress and loss of resources, can initiate new challenges and not only can they easily endure defeats, but they are also able to develop and improve their functioning. Resiliency is one of the important resources. Cardiologic patients with more intense resiliency tend to have greater flexibility in coping with stress than patients with lower resiliency. People with low psychological resil- 
iency, in a highly stressful situation, will be chaotic or rigid and limited, in contrast to people with high resiliency, who in the face of stress will be characterized by flexibility of behavior, thinking and emotions (Nadolska \& Sęk, 2007).

The analysis showed that the resiliency dimensions 'Persistence and determination in action' and 'Openness to new experiences and sense of humor' allow one to predict the greatest flexibility in coping with stress in cardiac patients. Persistence and determination in action suggest the importance of conscientiousness while performing the task for being flexible. However, openness to new experiences and sense of humor suggest that those who have distance to themselves and their ideas and are curious about new experience are more flexible. In general, a higher resiliency is expected to result in flexible coping. The results obtained largely correspond with reports from studies referring to factors supporting the health of people experiencing trauma, which showed that optimism and social support are the strongest predictors in predicting mental health (Segovia, Moore, Linnville, \& Hoyt, 2015; Porębska, 2009). The role of other personal resources in predicting the level of flexibility in coping of cardiac patients is an interesting area for research continuation.

The main limitation of this study concerns the method of data collection. Anonymity did not allow the group to be differentiated from the perspective of diagnosed cardiac diseases. This method of data collection was optimal for total anonymity, but at the same time caused that the sample was not a random one, because the questionnaires were completed only by interested persons.

Despite the limitations, the obtained research results bring new information into the area of the issue concerning the conditions of flexibility in coping with the stress of cardiac patients. They also confirm the significant role of psychological resiliency as a significant resource affecting the functioning of the individual. These results may also have practical significance, primarily in the process of adaptation to the disease. They emphasize the need to develop and shape psychological resiliency. The resiliency can be developed by stimulating high motivation to take new actions or change behaviors, among others thanks to shaping the sense of self-esteem and effectiveness, spirituality, creativity of independence or flexibility (Czapiński, 2002).

\section{CONCLUSIONS}

1. There is a positive relationship between resiliency and flexibility in coping with stress in cardiac patients.

2. People with a higher intensity of resiliency in comparison to people with lower intensity of re- siliency are characterized by greater flexibility in coping with stress.

3. The dimensions of resiliency, in particular 'Persistence and determination in action' and 'Openness to new experiences and sense of humor', together with the duration of the disease, play a predictive role for flexibility in coping with stress.

\section{ACKNOWLEDGEMENTS}

This work is supported by the National Center for Science [Grant number 2016/21/B/HS6/03786].

\section{ENDNOTE}

1 Access to medical records was not obtained.

\section{RefERENCES}

Basińska, M. A. (2015). Polska wersja Skali Elastycznego Radzenia Sobie - podsumowanie wyników badań [Polish version of Coping Flexibility Scale - the summary of research results]. In M. A. Basińska (Ed.), Elastyczne radzenie sobie ze stresem w zdrowiu i w chorobie [Coping flexibility with stress in health and in disease] (pp. 273-294). Bydgoszcz: Wydawnictwo UKW.

Basińska, M. A., \& Rusek, A. (2015). Temperament a elastyczne radzenie sobie ze stresem w grupie studentów kierunków artystycznych [Temperament and coping flexibility in a group of art students]. In M. A. Basińska (Ed.), Elastyczne radzenie sobie ze stresem $w$ zdrowiu $i$ w chorobie [Coping flexibility with stress in health and in disease] (pp. 123-140). Bydgoszcz: Wydawnictwo UKW.

Basińska, M. A., Sołtys, M., Kruczek, A., Grzankowska, I., Borzyszkowska, A., Janicka, M., Góralska, K., \& Stępka-Tykwińska E. (in print). Kwestionariusz Elastyczności w Radzeniu Sobie ze Stresem: konstrukcja i wtaściwości psychometryczne [Flexibility in coping with Stress Questionnaire: structure and psychometric properties].

Block, J. H., \& Block, J. (1980). The role of ego-control and ego-resiliency in the organization of behavior. In W. A. Collins (Ed.), Development of cognition, affect, and social relations: The Minnesota symposia on child psychology (Vol. 13, pp. 39-101). Hillsdale, NJ: Lawrence Erlbaum.

Block, J., \& Kremen, A. M. (1996). IQ and ego-resiliency: Conceptual and empirical connections and separateness. Journal of Personality and Social Psychology, 70, 349-361.

Cheng, C. (2001). Assesing coping flexibility in real-life and laboratory settings: a multimethod approach.
Resiliency predictor of flexibility in coping 
Journal of Personality and Social Psychology, 80, 814-833.

Cierniak-Piotrowska, M., Marciniak, G., \& Stańczak, J. (2015). Statystyka zgonów i umieralności z powodu chorób układu krążenia [Statistics of deaths and mortality due to cardiovascular diseases]. In Z. Strzelecki \& J. Szymborski (Eds.), Zachorowalność i umieralność na choroby układu krążenia a sytuacja demograficzna Polski [Morbidity and mortality of cardiovascular diseases and the demographic
Katarzyna Góralska, Małgorzata A. Basińska situation of Poland] (pp. 46-81). Warszawa: Rządowa Rada Ludnościowa.

Czapiński, J. (2002). Szczęśliwy człowiek w szczęśliwym społeczeństwie? Zrównoważony rozwój, jakość życia i złudzenie postępu [Happy man in a happy society? Sustainable development, quality of life and the illusion of progress]. Psychologia Jakości Życia, 1, 9-34.

Felcyn-Koczewska, M., \& Ogińska-Bulik, N. (2011). Rola prężności w rozwoju potraumatycznym osób $\mathrm{w}$ żałobie [The role of resilience in posttraumatic development of people in mourning]. In L. Golińska \& E. Bielawska-Batorowicz (Eds.), Rodzina i praca w warunkach kryzysu [Family and work in crisis] (pp. 511-524). Łódź: Wydawnictwo Uniwersytetu Łódzkiego.

Fredrickson, B. (2001). The role of positive emotions in positive psychology: The broaden-and build theory of positive emotions. American Psychologist, 56, 218-226.

Gil, K., Radziwiłłowicz, P., Zdrojewski, T., Piwoński, J., Landowski, J., \& Wyrzykowski, B. (2006). Depresja jako czynnik ryzyka chorób układu sercowo-naczyniowego [Depression as a risk factor for cardiovascular disease]. Kardiologia Polska, 64, 526-531.

Grzankowska, I., Napora, E., \& Basińska, M. A. (in print). The resilience of mothers and their job satisfaction: differentiating role of single motherhood. Psychologia Spoteczna.

Henderson, N. (1996). Resiliency at school. Thousand Oaks, CA: Corvin Press.

Hobfoll, S. E. (1989). Conservation of resources: A new attempt at conceptualizing stress. American Psychologist, 44, 513-524.

Kasprzak, A., Basińska, M. A., \& Lewandowska, P. (2013). Resiliency and the subjective evaluation of health in mothers of children with Asperger's syndrome. Health Psychology Report, 1, 34-41.

Kato, T. (2012). Development of the coping flexibility scale: evidence for the coping flexibility hypothesis. Journal of Counseling Psychology, 59, 262-273.

Lazarus, R. S., \& Folkman, S. (1984). Stress, appraisal, and coping. New York: Springer.

Nadolska, K., \& Sęk, H. (2007). Społeczny kontekst odkrywania wiedzy o zasobach odpornościowych, czyli czym jest resilience i jak ono funkcjonuje [The social context of discovering knowledge about immune resources, or what resilience is and how it works]. In Ł. Kaczmarek \& A. Słysz (Eds.), Bliżej serca. Zdrowie i emocje [Closer to the heart. Health and emotions] (pp. 13-37). Poznań: Wydawnictwo Naukowe UAM.

Ogińska-Bulik, N. (2010). Prężność a jakość życia młodzieży [Resiliency and quality of life of young people]. Psychologia Jakości Życia, 1, 233-247.

Ogińska-Bulik, N. (2011a). Rola prężności w zapobieganiu negatywnym skutkom stresu zawodowego [The role of resiliency in preventing the negative effects of occupational stress]. In L. Golińska \& E. Bielawska-Batorowicz (Eds.), Rodzina i praca w warunkach kryzysu [Family and work in crisis] (pp. 485-498). Łódź: Wydawnictwo Uniwersytetu Łódzkiego.

Ogińska-Bulik, N. (2011b). Rola prężności psychicznej w przystosowaniu się kobiet do choroby nowotworowej [The role of resiliency in adjustment to cancer in women]. Psychoonkologia, 1, 26-35.

Ogińska-Bulik, N. (2012). Prężność a potraumatyczny rozwój u młodzieży [Resiliency and post-traumatic growth in adolescents]. In N. Ogińska-Bulik \& J. Miniszewska (Eds.), Zdrowie w cyklu życia człowieka [Health in the human life cycle] (pp. 73-85). Łódź: Wydawnictwo Uniwersytetu Łódzkiego.

Ogińska-Bulik, N. (2013). Pozytywne skutki doświadczeń traumatycznych, czyli kiedy łzy zamieniaja się w perty [Positive effects of traumatic experiences, or when tears turn into pearls]. Warszawa: Difin.

Ogińska-Bulik, N. (2015) The relationship between resiliency and posttraumatic growth following death of someone close. Journal of Death and Dying, 71, 233-244.

Ogińska-Bulik, N., \& Juczyński, Z. (2008a). Skala pomiaru prężności - SPP-25 [Scale of Resiliency Measurement - SPP-25]. Nowiny Psychologiczne, 3, 39-56.

Ogińska-Bulik, N., \& Juczyński, Z. (2008b). Osobowość, stres i zdrowie [Personality, stress and health]. Warszawa: Difin.

Ogińska-Bulik, N., \& Juczyński, Z. (2011). Prężność u dzieci i młodzieży: charakterystyka i pomiar polska skala SPP-18 [Resiliency in children and adolescents: characteristics and measurement polish scale SPP-18]. Polskie Forum Psychologiczne, 16, 7-28.

Ogińska-Bulik, N., \& Juczyński, Z. (2012). Prężność jako wyznacznik pozytywnych i negatywnych konsekwencji doświadczonej sytuacji traumatycznej [Resiliency as a determinant of positive and negative consequences experienced traumatic situation]. Polskie Forum Psychologiczne, 17, 395-410.

Oleś, P. (2000). Psychologia przełomu połowy życia [Psychology of the turn of the half of life]. Lublin: Wydawnictwo KUL.

Opuchlik, K., Wrzesińska, M., \& Kocur, J. (2009). Ocena poziomu stylów radzenia sobie ze stresem i poczucia umiejscowienia kontroli zdrowia u osób z chorobą niedokrwienną serca i nadciśnieniem 
tętniczym [The assessment of the level of coping style and health locus of control in patients with coronary heart disease and hypertension]. Psychiatria Polska, 43, 235-245.

Porębska, K. (2009). Wsparcie społeczne w warunkach izolacji jako wyznacznik skutecznej readaptacji [Social support in conditions of isolation as a determinant of effective readaptation]. Probacja, 2, 49-58.

Segovia, F., Moore, J. L., Linnville, S. E., \& Hoyt, R. E. (2015). Optimism predicts positive health in repatriated prisoners of war. Psychological Trauma, 7, 222-228.

Semmer, N. (2006). Personality, stress and coping. In M. Vollrath (Ed.), Handbook of Personality and Health. Chichester: Wiley

Sęk, H. (2008). Udział pozytywnych emocji w osiąganiu zdrowia [Participation of positive emotions in health achievement]. In I. Heszen \& J. Życińska (Eds.), Psychologia zdrowia. W poszukiwaniu pozytywnych inspiracji [Health psychology. In search of positive inspirations] (pp. 73-88). Warszawa: Academica Wydawnictwo SWPS.

Sęk, H., Kaczmarek, Ł., Ziarko, M., Pietrzykowska, E., \& Lewicka, J. (2012) Sprężystość psychiczna a dobrostan w chorobie przewlekłej - mediująca rola podmiotowego umocnienia i radzenia sobie [Resiliency and well-being in chronić diseases - mediating role of empowerment and coping]. Polskie Forum Psychologiczne, 17, 327-343.

Shen, B. J., Myers, H. F., \& McCreary, C. P. (2006). Psychosocial predictors of cardiac rehabilitation quality-of-life outcomes. Journal of Psychosomatic Research, 60, 3-11.

Strike, P. C., \& Steptoe, A. (2004). Psychosocial factors in the development of coronary artery disease. Progress in Cardiovascular Diseases, 46, 337-347.

Szwajca, K. (2014a). Dyskurs na temat resilience konteksty i aspekty praktyczne [Discourse on resilience - contexts and practical aspects]. Psychoterapia, 168, 99-107.

Szwajca, K. (2014b). Sprężystość (resilience) i odpowiedzi na doświadczenia urazowe - fascynujący i trudny obszar badań [Resilience and responses to the experience of trauma - a fascinating but difficult study area]. Psychiatria Polska, 48, 563-572.

Turkiewicz-Maligranda, A. (2014). Prężność osobowa jako osobowościowy zasób zdrowotny [Resilience as the personality resource of health]. Pieleggniarstwo i Zdrowie Publiczne, 4, 173-176.

Uchnast, Z. (1997). Prężność osobowa: Empiryczna typologia i metoda pomiaru [Personal resilience: Empirical typology and measurement method]. Roczniki Filozoficzne, 45, 27-49.

White, B., Driver, S., \& Warren, P. M. (2010). Resilience and indicators of adjustment during rehabilitation from a spinal cord injury. Rehabilitation Psychology, $55,23-32$ 